\title{
Identification of a Bacillus subtilis secretion mutant using a $\beta$-galactosidase screening procedure
}

\author{
Myra F. Jacobs, ${ }^{1} \dagger$ Jens B. Andersen, ${ }^{1}$ Torben V. Borchert ${ }^{1}$ and \\ Vesa P. Kontinen ${ }^{2}$
}

Author for correspondence: Myra F. Jacobs. Tel: +1 301405 5441. Fax: +1 3013149489.

\begin{abstract}
1 Department of Microbiology, Technical University of Denmark, 2880 Lyngby, Denmark

2 National Public Health Institute, Helsinki SF00300, Finland
\end{abstract}

\begin{abstract}
High-level synthesis of exportable $\beta$-galactosidase (Lacz) fusion proteins in Bacillus subtilis results in a lethal phenotype, and has been suggested as a tool for the selection of secretion mutants. We tested a plasmid-based, inducible lacz fusion gene system for this purpose, but frequent mutations in cis, which reduced expression of the fusion gene, forced abandonment of the inductionselection strategy. Instead, after modification of the indicator plasmid, a screening procedure for increased basal Lacz activity levels was adopted. This led to the identification of a conditional B. subtilis secretion mutant after nitrosoguanidine mutagenesis. At $42{ }^{\circ} \mathrm{C}$, but not at $30^{\circ} \mathrm{C}$, this mutant displayed extreme growth retardation when the Lacz fusion protein was produced, and was also defective in the secretion of subtilisin Carlsberg. The processing kinetics and secretion of a subtilisin Carlsberg-alkaline phosphatase fusion derivative were found to be defective specifically at the non-permissive temperature. The secretion defect was not linked to the secA/div locus.
\end{abstract}

Keywords: Bacillus, $\beta$-galactosidase, protein secretion, xylose

\section{INTRODUCTION}

Genetic approaches, supplemented by in vitro methods, have elucidated the protein translocation process in the Gram-negative bacterium Escherichia coli. Our present understanding of protein translocation in Gram-positive organisms, e.g. Bacillus subtilis, is more limited, despite their industrial utility for the production of secreted proteins, and is largely based on DNA homologies to secretion loci previously identified in other systems, e.g. $\sec A$ (Overhoff et al., 1991; Sadaie et al., 1991), secY (Nakamura et al., 1990; Suh et al., 1990), secE (Jeong et al., 1993) and ffh (Honda et al., 1993).

Only a few genetic approaches have been applied in $B$. subtilis to date. These have revealed apparently novel

\footnotetext{
†Present address: Department of Microbiology, University of Maryland, College Park, MD 20742, USA.

Abbreviations: APase, alkaline phosphatase; $\mathrm{Cm}$, chloramphenicol; Em, erythromycin; $\mathrm{Km}$, kanamycin; NNG, nitrosoguanidine; $O / P_{x y n}$ operatorpromoter of xylosidase gene; phoA, gene encoding APase PhoA; subC, gene encoding subtilisin Carlsberg, SubC; SubCp', SubC36', SubC267', denote respectively only pre-sequence, or prepro-sequence plus 36 or 267 residues of mature SubC; wt, wild-type/parental genotype; $x y / R$, xylose repressor-encoding gene; $x y n B$, xylosidase-encoding gene.
}

secretory loci, e.g. $\operatorname{prs} A$, encoding an extracytoplasmic chaperone affecting the amount of active exoenzyme released to the surroundings (Kontinen \& Sarvas, 1988; Jacobs et al., 1993), and sipS, encoding a non-essential signal peptidase (van Dijl et al., 1992).

To expand these investigations, we chose to adapt the most fruitful genetic approach from $E$. coli, viz. exploitation of the special properties of $\beta$-galactosidase (LacZ) fusion proteins which have a functional $\mathrm{N}$ terminal pre-sequence. These 'exportable' proteins display higher enzymic activity when confined to the cytoplasm than when found in the cytoplasmic membrane (Oliver \& Beckwith, 1981). Also, synthesis of elevated amounts of such proteins leads to lethality due to abortive transport/'membrane jamming' (Bassford et al., 1979; Phillips \& Silhavy, 1990), and consequent disruption of essential exoprotein precursor transport.

Overproduction of LacZ fusion proteins likewise led to lethality in $B$. subtilis, and was suggested as a means for selecting secretion mutants which failed to transport the proteins (Hastrup \& Jacobs, 1990; Zagorec \& Steinmetz, 1990). As we report here, we were able to isolate a $B$. subtilis mutant with a conditional secretion defect using an inducible expression system for an exportable subtilisin Carlsberg-LacZ (SubC'-' LacZ) indicator protein. 


\section{METHODS}

DNA, reagents. Plasmid isolation, DNA manipulation and electrophoresis were carried out by standard methods (Sambrook et al., 1989). DNA fragments were isolated from gels using Geneclean (Bio 101). Enzymes were obtained from New England Biolabs and Boehringer Mannheim; isotope was obtained from Amersham.

Bacterial strains. $B$. subtilis strains $168 \operatorname{trp} C 2$ (BGSC 1A1), $3 \mathrm{G} 18$ $\operatorname{trp} C 2 \operatorname{pur} A$ met (supplied by J.-I. Flock, Karolinska Institute, Huddinge, Sweden), NIG1121 his met and $\sec A /$ div-341 derivative NIG1152 (Sadaie \& Kada, 1983) were used. Mutagenesis of 3G18 (wild-type: wt) yielded MFJ566. It had no additional auxotrophic requirements. $\mathrm{Met}^{+}$derivatives were obtained by transformation of competent cells (Boylan et al., 1972) with dilutions of $B$. subtilis 168 chromosomal DNA, and selection on minimal medium with relevant auxotrophic requirements.

Media. LB (Sambrook et al., 1989) was used as the rich medium throughout. Chloramphenicol $(\mathrm{Cm})$, erythromycin $(\mathrm{Em})$ or kanamycin $(\mathrm{Km})$ at respectively 6,5 or $10 \mu \mathrm{g} \mathrm{ml}^{-1}$, as appropriate, were added to media for plasmid maintenance. Xylose was added to media to induce transcription from $O / P_{x y n}$. To detect LacZ activity on plates $40 \mu \mathrm{g} \mathrm{X}-\mathrm{Gal} \mathrm{ml}{ }^{-1}$ was used.

Plasmids. pM J57 (Jacobs, 1995), pM J67 and pTVB50 (Hastrup \& Jacobs, 1990; Jacobs et al., 1993) were derivatives of pSX50 (Hastrup, 1993), a pUB110-based replicon (McKenzie et al., 1987). pM J550 (this study), pJBA221 and pJBA222 (Jacobs et al., 1993) were based on the pAM $\beta 1$ derivative pIL252 (Simon \& Chopin, 1988). All supported xylose-inducible synthesis of SubC-related products. pMJ57 encodes SubC; pTVB50 and pMJ550, SubCp'-'LacZ; pMJ67 and pJBA222, respectively, SubC36'-'LacZ and SubC36'-'PhoA; and PJBA221, SubC267'-'PhoA, with the SubC moieties defined as in the list of abbreviations. pSX50 derivatives carry a copy of the xylose repressor gene, $x y / R$, and induction ratios were typically $100-150$. In pIL252 derivatives, induction ratios were $\leqslant 10$, due to titration of chromosomally-encoded XylR, and low plasmid copy number (Jacobs et al., 1993). pUB110-based plasmids pKTH271, encoding $B$. licheniformis $\beta$-lactamase (Simons et al., 1978), and pBS613 (kindly supplied by Georges Rapoport, Institut Pasteur, Paris, France), encoding B. subtilis levansucrase, were also employed.

Construction of subC-lacZ indicator plasmids. pM J67 (Fig. 1) has been described (Hastrup \& Jacobs, 1990). pTVB50 (Fig. 1) was derived from pM J67 by replacing sequences between $\mathrm{HpaII}$ (just $3^{\prime}$ from the subC-encoded pre-sequence) and HindIII (at the junction with 'lacZ), with a synthetic linker (5'-CGTTCGCGAA-3' and 5'-AGCT'TTCGCGAA-3', kindly provided by Novo-Nordisk A/S, Bagsværd, Denmark) having compatible ends bracketing a NruI site. Recloning of $s u b C-$ lacZ to pIL252 (Simon \& Chopin, 1988) by ligating pTVB50 474 bp EcoRIHindIII $O / P_{x y n}-s u b C p^{\prime}$ and $3.3 \mathrm{~kb}$ HindIII-BamHI 'lacZ fragments with the pIL252 $4.7 \mathrm{~kb}$ EcoRI-BamHI segment yielded pM J550. Further properties of these plasmids are described in the preceding section.

Mutagenesis. Nitrosoguanidine (NNG) mutagenesis of $3 \mathrm{G} 18$ carrying either pTVB50 or PM J550 was performed in buffer, as described previously (Kontinen \& Sarvas, 1988). After exposure, cells were washed twice in buffer, then incubated in LB for $4 \mathrm{~h}$ at $30^{\circ} \mathrm{C}$, after which dilutions were plated on $\mathrm{LB} / \mathrm{X}-\mathrm{Gal}$ agar with an appropriate antibiotic, with or without xylose, as described in the text, and incubated at $30^{\circ} \mathrm{C}$. Residual NNG was inactivated with $0.2 \mathrm{M} \mathrm{HCl}$. Batches in which the mutagenesis survival frequency was about $1 \%$ were pursued. In the experiment in which MFJ566 was identified, a total of approxi- mately 20000 colonies was screened, at a density of about 2500 per plate. Blue colonies were scored after $1 \mathrm{~d}$ incubation and subsequently disregarded, as these were expected to involve either pre-sequence mutations (Kumamoto \& Beckwith, 1983), or the $B$. subtilis chromosomal $\beta$-galactosidase genes (Errington \& Vogt, 1990; Zagorec \& Steinmetz, 1991). After an additional $5 \mathrm{~d}$, approximately 40 newly sectored or deep blue colonies were picked. Half survived purification, and were tested for possible temperature-related growth defects. Overnight growth without antibiotic selection cured the cells of pM J550 (Simon \& Chopin, 1988).

Mapping mutations to/in pTVB50. A plasmid-borne mutation was indicated by a plating efficiency ratio approaching 1 for 3G18 transformed with plasmid extracted from induction survivors, determined on $\mathrm{LB} / 2 \%(\mathrm{w} / \mathrm{v})$ xylose, compared with $0 \%$ xylose. Mutations were further localized in five pTVB50 variants having unaltered pre-sequences, by individually recloning the $470 \mathrm{bp}$ EcoRI-HindIII $O / P_{x y n}-s u b C p^{\prime}$ and $1.8 \mathrm{~kb}$ EcoRI-BglI ori fragments to appropriate, purified fragments of the related pM J67. Restriction analysis verification of recloning was simple due to the $324 \mathrm{bp}$ larger $s u b C$ fragment size of pMJ67. Recombinant plasmids were tested for transfer of resistance to transformants as described above.

$\boldsymbol{x y} / \boldsymbol{R}$ function test. $x y / \mathrm{R}$ integrity was tested by monitoring xylose induction of xylosidase encoded by the chromosomal $x y n B$ (Hastrup, 1988), and in some cases, also of plasmidencoded products. In cultures carrying pTVB50 variants, xylosidase activity was measured after growth at $30^{\circ} \mathrm{C}$ to $\mathrm{OD}_{600}$ 1.5 in $\mathrm{LB}$ with $0.2 \%(\mathrm{w} / \mathrm{v})$ xylose. SubC'- ${ }^{\prime} \mathrm{LacZ}$ activity of these cultures was measured after growth to $\mathrm{OD}_{600} 0.5$ in $\mathrm{LB}$, and a further $1 \mathrm{~h}$ incubation with $0 \cdot 2 \%$ xylose. Xylosidase activity was determined for 3 G18 and MFJ 566 cultures, sampled regularly between $\mathrm{OD}_{450} 0.5$ and 8.0 , during growth at $30^{\circ} \mathrm{C}$, and at $42{ }^{\circ} \mathrm{C}$, in LB containing $0.05 \%(\mathrm{w} / \mathrm{v})$ or $0.2 \%$ xylose. Xylosidase activity versus $\mathrm{OD}_{450}$ for both strains was the same under all conditions tested.

Plate screening of LacZ, temperature-sensitive phenotypes. Lac Z phenotype was determined on LB/X-Gal agar after 28-40 h incubation at $30^{\circ} \mathrm{C}$, unless otherwise stated. Mutants were tested for temperature-sensitive growth by quadruplicate streaking to single colonies on $\mathrm{LB}$ agar with and without xylose, followed by incubations at $30^{\circ} \mathrm{C}$ and $42{ }^{\circ} \mathrm{C}$.

Enzyme assays. The activities of xylosidase (Hastrup \& Jacobs, 1990), alkaline phosphatase (APase) (Jacobs et al., 1993), exoprotease and LacZ (Jacobs, 1995), $\alpha$-amylase and $\beta$-lactamase (Kontinen \& Sarvas, 1988) were assayed as previously described.

Disc sensitivity assay. LB cultures of $\mathrm{Met}^{+}$derivatives of $3 \mathrm{G} 18$ and MFJ566, and their non-induced pM J550 transformants, growing exponentially at $30^{\circ} \mathrm{C}$, were diluted to identical cell densities and spread on LB agar. Discs $(5 \mathrm{~mm})$ with respectively $6,15,5,30$ and $5 \mu \mathrm{g}$ of $\mathrm{Cm}, \mathrm{Em}, \mathrm{Km}$, novobiocin and rifampicin were tested. Similarly, discs with $10 \mathrm{ml}$ of $1 \%$ solutions of the detergents sodium dodecyl sulphate, Sarkosyl and Triton-X 100 , and $0 \cdot 1 \mathrm{M} \mathrm{CoCl}_{2}, \mathrm{Na}_{2} \mathrm{Cr}_{2} \mathrm{O}_{7}$ and $\mathrm{CuSO}_{4}$, were tested. Clear zones of growth inhibition were measured after $18 \mathrm{~h}$ incubation at $30^{\circ} \mathrm{C}$.

Immunoblot analysis and cell fractionation. Immunoblotting of cell and medium samples was as described for PhoA (Jacobs et al., 1993) and SubC (Jacobs, 1995). Membranes were prepared from $10 \mathrm{ml}$ culture by lysozyme treatment of cells $\left(0.5 \mathrm{mg} \mathrm{ml}^{-1}\right.$, $37^{\circ} \mathrm{C}, 15 \mathrm{~min}$ ) in the presence of $1 \mu \mathrm{g} \mathrm{DNase} \mathrm{Iml}^{-1}$ and $10 \mathrm{mM}$ $\mathrm{MgCl}_{2}$, and sonication to complete lysis (Branson sonifier 250, 30 bursts at output and duty cycle of 4.5). A clearing 
pMJ67

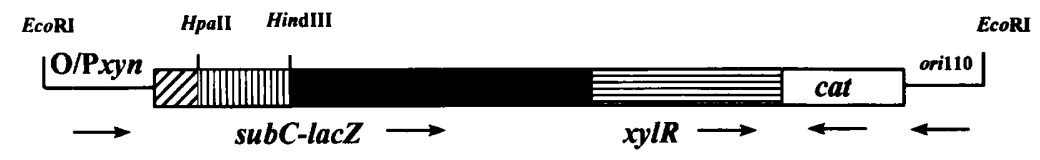

pTVB50

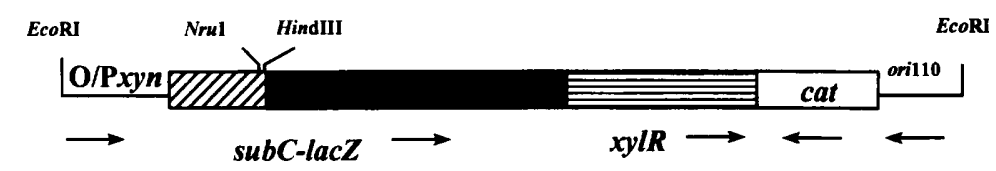

.pMJ550

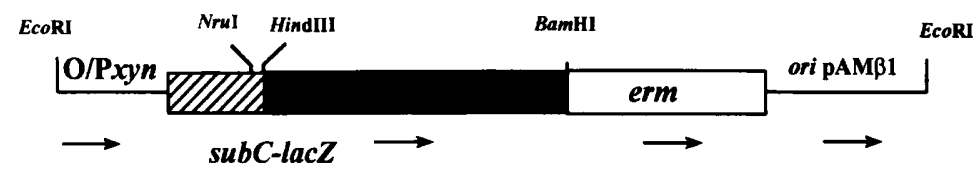

Fig. 1. Maps of subC'-lacZ indicator plasmids. pMJ67 (8.1 kb) has been described (Hastrup \& Jacobs, 1990); pTVB50 (7.8 kb) and pMJ550 (8.1 kb) were successively derived from it (see Methods). The diagrams are not to scale, and restriction sites indicated are not necessarily unique. $O / P_{x y n}$ $B$. subtilis $x y \cap B$ operator-promoter; subC'-'lacZ, SubC'-'LacZ fusion gene (diagonal stripes denote subC pre-region; vertical stripes, pro- and 36 codons of mature region; solid bar, 'lacZ moiety); $x y / R$, xylose repressor gene (horizontal stripes); cat, $\mathrm{Cm}$ transacetylase gene; erm, Em resistance gene (open boxes); ori110, oripAM $\beta 1$, replication regions derived from, respectively, pUB110 and pAM $\beta 1$. The direction of ori in pMJ67 was previously indicated erroneously (Hastrup \& Jacobs, 1990). centrifugation step (10 $\mathrm{min}, 1000 \mathrm{~g}$ ) was followed by membrane collection ( $200000 \mathrm{~g}, 45 \mathrm{~min})$. The gelatinous membrane pellet was resuspended in water and proteins were precipitated, and further treated, as before (Jacobs et al., 1993). Coomassie staining of samples in protein gels was used to normalize immunoblot sample loadings for variable membrane yields.

Pulse-chase labelling and SubC-PhoA immunoprecipitation. These were performed as previously described (Jacobs et al., 1993).

DNA sequencing. Sequencing of drop-dialysed (Marusyk \& Sargeant, 1980) double-stranded plasmid DNA was performed with a Sequenase kit (USB), and universal lac $Z$ primers.

Sporulation frequency. Dilutions of $10 \mathrm{ml}$ cultures grown at $30^{\circ} \mathrm{C}$ for $24 \mathrm{~h}$ in Sporulation medium (Schaeffer et al., 1965) were titrated on LB agar before (c.f.u.) and after (spores) heattreatment $\left(80^{\circ} \mathrm{C}, 15 \mathrm{~min}\right)$. Sporulation frequency was calculated as (percentage spores)/(c.f.u.).

\section{RESULTS}

\section{lacZ fusion expression is detrimental to B. subtilis}

SubC-LacZ fusion protein overproduction from plasmid pM J67 has a lethal effect in B. subtilis (Hastrup \& Jacobs, 1990). Studies in E. coli have shown that mutations which reduce translocation of an exportable Lac Z fusion protein can result in its cytoplasmic accumulation (and a $\mathrm{Lac}^{+}$ phenotype), and may also reduce the deleterious effects of membrane jamming (Schatz \& Beckwith, 1990). pTVB50, identical to pM J67 but with a smaller subC moiety (Fig. 1), was tested as a tool for the identification of translocation mutants. In pM J67 and pTVB50, subC'-'lac $Z$ expression is under xylose control via the xylosidase operatorpromoter, $O / P_{x y n}$. We reasoned that employing the relatively simple xylose system, rather than the native $s u b C$ promoter, which is regulated by many pleiotropic factors (Jacobs, 1995), would reduce the chance of isolating mutants defective in SubC'- $\mathrm{LacZ}^{\prime}$ synthesis, rather than its translocation. $O / P_{x y n}$ also permitted sub $C^{\prime}-{ }^{\prime} l a c Z$ expression manipulation by alterations in xylose concentrations. Increasing xylose levels caused progressively higher LacZ activity in 3G18(pTVB50), concomitant with colony size and plating efficiency reductions. These were associated with gross cell elongation and lysis. There was an abrupt fall in plating efficiency from $0.03-0.83$ to $3.3-8 \times 10^{-5}$, as inducer was increased from 0.2 to $2 \%(\mathrm{w} / \mathrm{v})$. Colonies surviving on $2 \%$ xylose were strikingly heterogeneous in size and LacZ phenotype, suggesting that a mutational event was required to counteract the effects of SubCp' $-^{\prime} \mathrm{LacZ}$ overproduction. These observations confirmed data obtained with pMJ67 (Hastrup \& Jacobs, 1990).

\section{LacZ $Z^{+}$survivors have plasmid mutations mainly in xylR}

Many E. coli secretion factors are essential for cell viability (Schatz \& Beckwith, 1990); the ratio of conditional to non-lethal secretion locus mutants obtained can be as high as $1: 5$ (Kumamoto \& Beckwith, 1983). We thus sought conditional B. subtilis secretion mutants among $\mathrm{LacZ}^{+}$ 3G18(pTVB50) survivors of SubC $\mathrm{p}^{\prime}-{ }^{\prime} \mathrm{LacZ}$ induction on $2 \%$ xylose agar. However, no clones displaying temperature-sensitive growth were found among several hundred such spontaneous or chemically-mutagenized survivors. In all cases examined, the xylose resistance could be transferred to competent cells by plasmid extracted from the mutant. We expected these cis mutations to be mainly in the subC pre-sequence region (Kumamoto \& Beckwith, 1983), but sequencing showed that this was not the case in 20 randomly chosen mutants. Recloning experiments and/or $x y / R$ function tests on 11 mutant plasmids localized the resistant phenotype to $O / P_{x y n}$ in a single case. In all others, the lesion was in $x y / \mathrm{R}$. Hence survival was due to SubC $\mathrm{p}^{\prime}-{ }^{\prime} \mathrm{Lac} Z$ synthesis reductions to non-lethal levels by changes primarily in the repressor protein, or at the operator/promoter.

\section{Modifications to the subCp'-'lacz system}

To reduce the rate of indicator plasmid mutations, subC $C p^{\prime}-{ }^{\prime} l a c Z$ was recloned to a different replicon, yielding pMJ550, which does not carry $x y / R$ (Fig. 1). 'Theta'- 


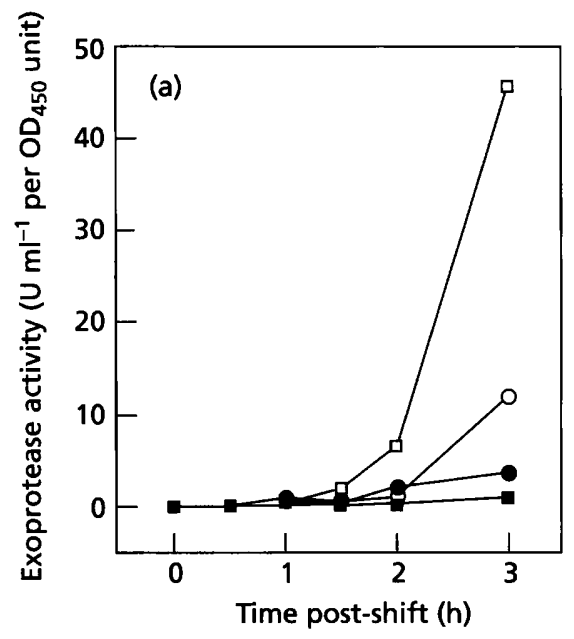

(b)

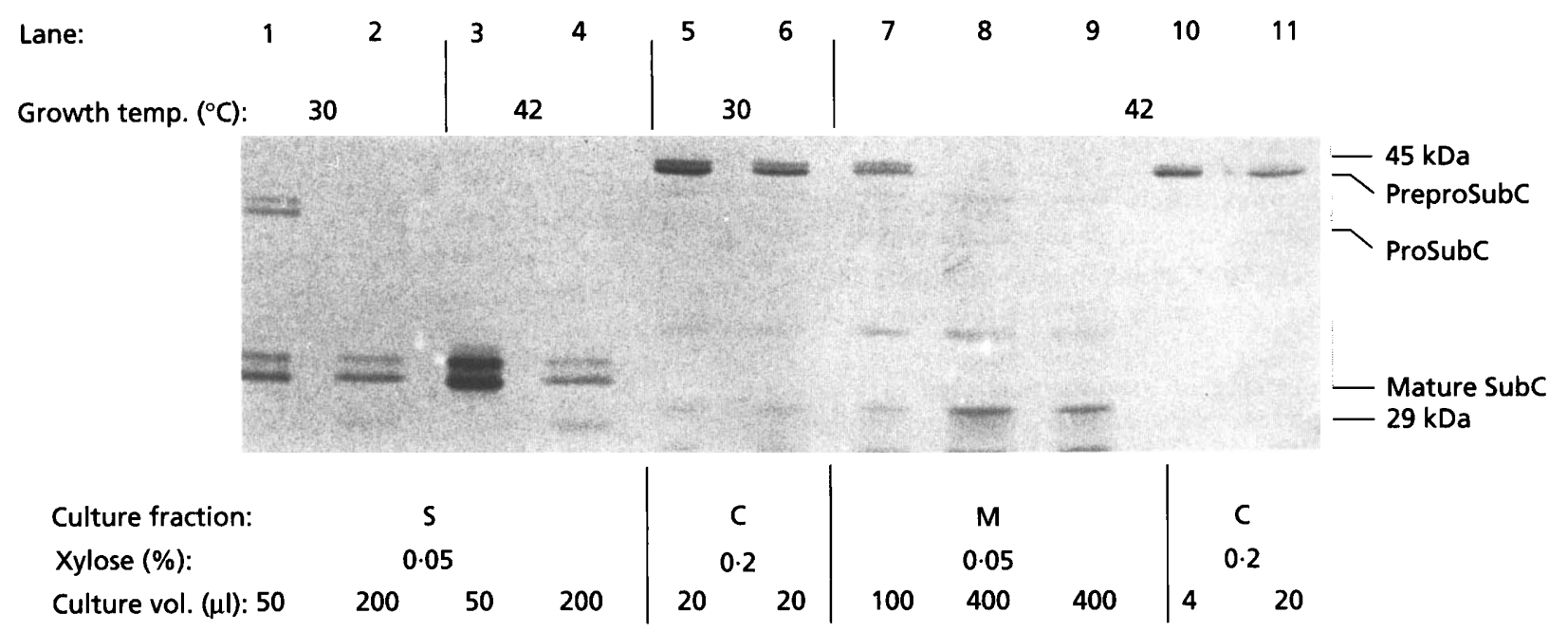

Fig. 2. Effect of temperature shift on SubC secretion. Fresh overnight cultures of wt $3 G 18 \mathrm{Met}^{+}$(pMJ57) and mutant MFJ566 Met $^{+}$(pMJ57) were diluted to $O_{450} 0.05$ in $200 \mathrm{ml} \mathrm{LB}$ containing Cm and $0.05 \%$ xylose, and grown with moderate agitation in $1 \mathrm{I}$ baffled flasks at $30^{\circ} \mathrm{C}$ to $\mathrm{OD}_{450} 0.25$. Cultures were divided into two aliquots, transferred to prewarmed $500 \mathrm{ml}$ baffled flasks, and incubated for a further $3 \mathrm{~h}$ either at $30^{\circ} \mathrm{C}$ or at $42{ }^{\circ} \mathrm{C}$, during which time samples were withdrawn for exoprotease activity assays and immunoblotting. As no SubC-specific signal was obtained in blots from any cell fractions at $30^{\circ} \mathrm{C}$, nor from the $42{ }^{\circ} \mathrm{C}$ mutant membranes, the experiment was repeated with $0.2 \%$ xylose, and cell and membrane samples prepared. (a) Exoprotease activity. Exoprotease activities were normalized for cell density at the indicated sampling times. Final sampling occurred at times corresponding to approximately $1 \mathrm{~h}\left(30^{\circ} \mathrm{C}\right)$, and $2 \mathrm{~h}$ $\left(42{ }^{\circ} \mathrm{C}\right)$ after the cessation of exponential growth. Background exoprotease activity (i.e. not due to SubC) was not detectable under these conditions of early xylose induction. Open symbols, wt; filled symbols, mutant; circles, $30^{\circ} \mathrm{C}$; squares, $42^{\circ} \mathrm{C}$. (b) Subcellular distribution of SubC. Samples were taken at $3 \mathrm{~h}$ post-shift, and immunoblotted. In this experiment all the SubC proteins migrated as doublets due to incomplete denaturation: reboiling with additional $\beta$ mercaptoethanol caused a shift of most (but not all) material from the upper band of each doublet to the lower, i.e. to the position at which they normally run. Growth temperature, xylose concentration, cellular fraction $(S$, medium; $C$, cell; $M$, membrane) and culture volume equivalent are indicated. The positions of size standards and SubC species are shown. The $38 \mathrm{kDa}$ proSubC was never observed in $42^{\circ} \mathrm{C}$ samples (Jacobs, 1995). Lanes $1,3,5,7,10$, wt; lanes 2, 4, 6, 8, 11, mutant; lane 9, control $3 \mathrm{G} 18 \mathrm{Met}^{+}$(no subC plasmid).

replicating plasmids (like the pAM $\beta 1$-based pMJ550) have greater structural integrity (Jannière et al., 1990) than plasmids (like pMJ67 or pTVB50) which multiply by a rolling-circle mechanism. This factor, the low copy number of $\mathrm{pMJ} 550$, and the reduction in $x y / R$ dosage to the single chromosomal copy (whose integrity could readily be tested), were expected to counteract the tendency of $O / P_{x y n}$, and especially $x y / R$, to mutate. As a result of the modifications, the induction ratio of 3G18(pM 550) cultures differed markedly from 3G18(pTVB50): basal/maximal activities were respectively $88 / 150$ units and 2:3/1300 units. Maximal activity from the new plasmid was achieved at lower xylose levels $(0.005$ vs $0.2 \%-2 \%)$. In sharp contrast to 

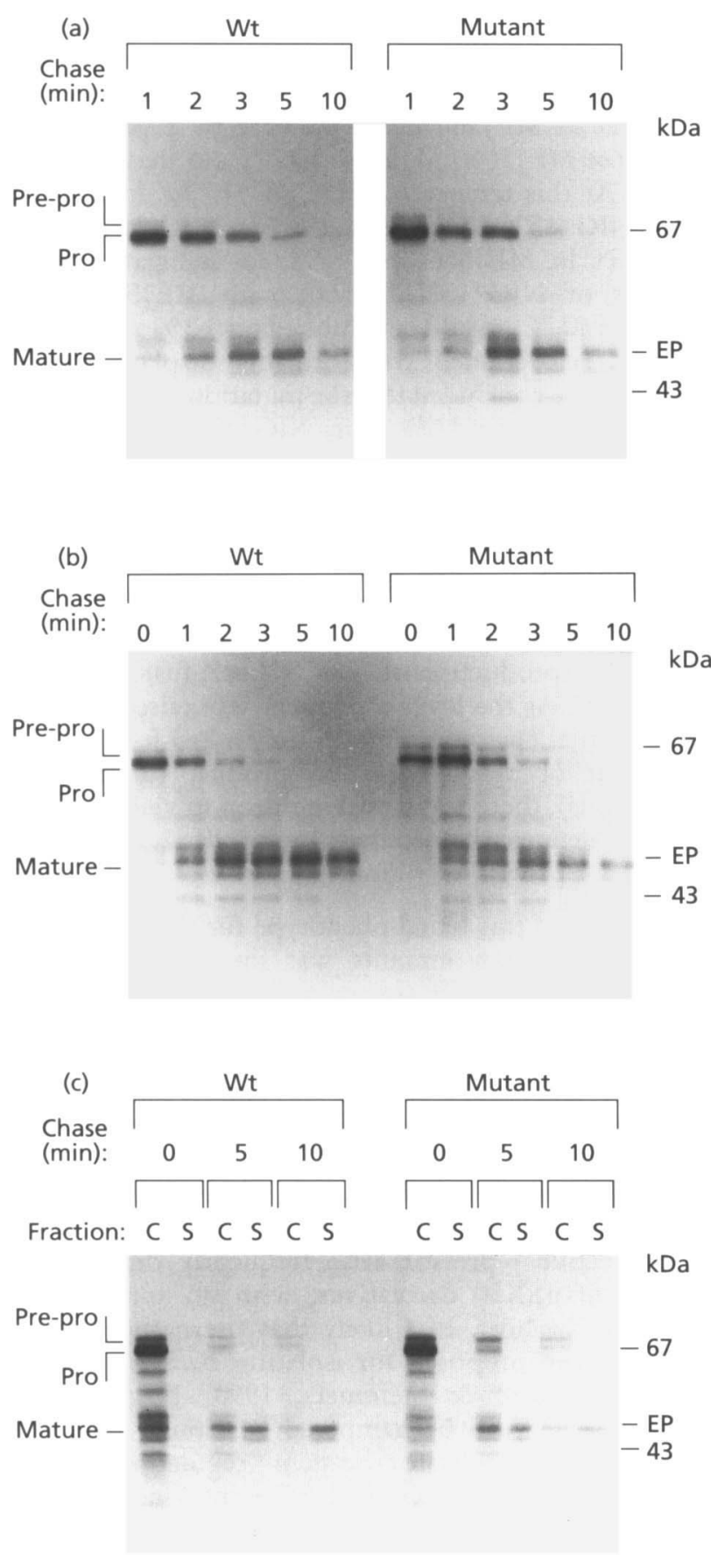

Fig. 3. Synthesis and processing of SubC36'-'PhoA. Cultures of wt 3G18 $\mathrm{Met}^{+}$(pJBA222) and mutant MFJ566 $\mathrm{Met}^{+}$(pJBA222) were grown at $30^{\circ} \mathrm{C}$ in modified Spizizen's medium containing Em to $O D_{450} 0 \cdot 25$, then half of each culture was shifted to $42{ }^{\circ} \mathrm{C}$, as described in the legend to Fig. 2. At $O D_{450} 1$, half of each culture was induced by addition of xylose to $0.2 \%$. Pulse-chase experiments were conducted on aliquots of induced cultures $2 \mathrm{~h}$ later. Samples were withdrawn for APase activity determination at hourly intervals up to $5 \mathrm{~h}$ post-shift, and for immunoblotting at $3 \mathrm{~h}$ post-induction. The results are shown as an autoradiogram of pulse-labelled SubC36-PhoA. The positions of size markers, SubC'-'PhoA pre-pro- and pro-form precursors, as well as fully processed mature SubC'-'PhoA are shown. EP denotes the position of authentic $E$. coli PhoA. (a, b) Unfractionated cultures grown at $30^{\circ} \mathrm{C}$ (a) and at $42^{\circ} \mathrm{C}$ (b); (c) cultures grown at $42{ }^{\circ} \mathrm{C}$ and separated into cell (C) and medium (S) fractions.
3G18(pTVB50), $2 \%$ xylose did not detectably reduce $3 \mathrm{G} 18$ (pMJ550) colony size.

\section{Isolation of secretion mutant}

Variations in LacZ fusion protein enzymic activity with their subcellular location in E. coli were most pronounced at low synthesis levels (Oliver \& Beckwith, 1981). We thus screened colonies of $3 \mathrm{G} 18$ (pM J550) for raised noninduced LacZ activity on LB/X-Gal agar after NNG mutagenesis.

Among 20 such purified mutants, one displayed severe temperature-dependent growth inhibition, but only when sub $C p^{\prime}-{ }^{\prime} l a c Z$ was induced: colonies grown at $42{ }^{\circ} \mathrm{C}$ on $0.2 \%$ xylose agar averaged $0.5 \mathrm{~mm}$ in diameter versus $6 \mathrm{~mm}$ for the wt. Under other conditions the size of this mutant was only slightly reduced relative to the wt. The cured mutant, called MFJ566, had the same auxotrophic requirements as the wt. However, satisfactory growth in minimal media of mutant carrying either pMJ550 or pBS613 could not be achieved, and MFJ566 was sensitive to $0.1 \mathrm{mM}$ cobalt salts when carrying plasmids encoding SubC-PhoA fusion proteins. These problems were not encountered with a variety of other test plasmids, which also encoded secretory proteins. Sensitivity assays revealed that membrane permeability, and tolerance towards a wide range of agents, was not detectably altered in MFJ566. MFJ566 was examined for possible secretory defects as described below; the secretory status of the other 19 mutants was not examined.

\section{Elevated SubCp-LacZ activity in MFJ566}

Confirming the results of the screening method, basal, as well as induced LacZ activity in exponentially growing MFJ566(pM J550) were slightly elevated at $30^{\circ} \mathrm{C}$ over parental levels, e.g. 15 vs 10 Miller units at $\mathrm{OD}_{450} 0 \cdot 25$, with $0.005 \%$ xylose. As chromosomal $x y / R$ function testing showed that this elevation was not due to defective xylose regulation, the most likely explanation was that a reduced fraction of synthesized SubCp-LacZ was transported from the cytoplasm.

For technical reasons we could not demonstrate reduced translocation directly with SubCp-LacZ. The SubCpLacZ fusion protein displayed no enzymic activity at $42{ }^{\circ} \mathrm{C}$, precluding assay for assessment of cytoplasmic accumulation. Pulse-chase labelling could not be used to monitor the kinetics of translocation-associated prepeptide removal (Phillips \& Silhavy, 1990), because MFJ566 carrying SubC-LacZ-encoding plasmids failed to grow satisfactorily in a variety of minimal media.

As an alternative, we examined the effect of growth at $42{ }^{\circ} \mathrm{C}$ on the secretion of proteins that were related to SubCp'- LacZ.

\section{SubC secretion defective at $42{ }^{\circ} \mathrm{C}$}

Mutant cultures in which synthesis of SubC had been induced prior to a temperature-shift from $30{ }^{\circ} \mathrm{C}$ to $42{ }^{\circ} \mathrm{C}$ 
had greatly reduced exoproteolytic activity relative to the wt (Fig. 2a). This effect was highly reproducible: in three experiments, there were no significant differences at $30^{\circ} \mathrm{C}$ between the low activities seen in wt and mutant. At $42{ }^{\circ} \mathrm{C}$, however, while exoproteolytic activity accumulated rapidly in the wt, there was no net increase in the mutant. These measurements correlated with amounts of extracellular SubC protein detected in immunoblots (Fig. $2 \mathrm{~b})$. But as cell- or membrane-associated SubC precursors were also significantly reduced in MFJ566, it was essential to determine whether this was due to differential synthesis, or to post-translational events. To resolve this question we performed kinetic studies employing SubC'-'PhoA hybrid proteins (Jacobs et al., 1993).

\section{SubC'-'PhoA processing kinetics at $42^{\circ} \mathrm{C}$}

Temperature-shift experiments (Fig. 3) were performed on wt and mutant cultures after induction of the pJBA222borne subC 36'-'phoA gene (Jacobs et al., 1993). There were no differences between mutant and wt in either measured APase activities or amounts of anti-PhoA specific protein in culture fractions at $30^{\circ} \mathrm{C}$ (data not shown). But at $42^{\circ} \mathrm{C}$ both SubC $36^{\prime}-{ }^{\prime}$ PhoA in the medium fraction as well as APase activity were reduced severalfold in the mutant (data not shown), reflecting the results with SubC. Crucially, pulse-chase analysis demonstrated similar rates of synthesis of SubC $36^{\prime}-{ }^{\prime}$ PhoA in wt and mutant: there were no significant differences in the amount of incorporated isotope at the end of the pulse period (Fig. 3a-c; 0, $1 \mathrm{~min}$ ). It was notable that, specifically at $42{ }^{\circ} \mathrm{C}$, cell-associated precursor forms persisted longer in the mutant, and that a smaller fraction of labelled protein was chased into the medium fraction ('S'), compared with the wt, consistent with our steadystate observations. Similar steady-state and kinetic data were obtained with pJBA221-encoded SubC267'-'PhoA (data not shown).

\section{Effect on secretion of other enzymes}

To determine whether the defect in MFJ566 affected exoenzyme secretion in general, we examined the effect of a temperature-shift on a number of other enzymes. Activity levels of chromosomally encoded AmyE $(\alpha-$ amylase) in cured MFJ566 at $6 \mathrm{~h}$ post-shift were depressed to $60 \%$ of wt levels at $42{ }^{\circ} \mathrm{C}$, while they were $85 \%$ relative to wt at $28{ }^{\circ} \mathrm{C}$. In contrast, no effect on the secretion of a heterologous $\beta$-lactamase was found when cultures carrying pKTH271 were studied. The colonial morphology of MFJ566(pBS613) induced to overproduce levansucrase on $2 \%$ sucrose agar was strikingly different from the wt control at $42{ }^{\circ} \mathrm{C}$; colonies were much less mucoid, suggesting less sucrose-derived levan around the colony. We could not confirm any effect on processing of levansucrase as MFJ566(pBS613) did not grow adequately in minimal medium.

\section{Mutation in MFJ566 is not linked to secA}

E. coli $\sec A$ (Oliver \& Beckwith, 1981; Kumamoto \& Beckwith, 1983), secB (Kumamoto \& Beckwith, 1983) and $\sec D$ (Gardel et al., 1987) loci were identified by screening regimens similar to that applied here. As the $B$. subtilis $\sec A$ homologue is known, we could readily test whether the defect in MFJ566 involved $\sec A$ by exploiting the viability of MFJ566(pM J550) at $42{ }^{\circ} \mathrm{C}$ (in the absence of xylose). At this temperature the $\operatorname{div}-341 \sec A$ mutant $B$. subtilis NIG1152 cannot grow (Sadaie \& Kada, 1983). If the defect in MFJ566 was $\sec A / d i v$ associated, transformants of NIG1152(pMJ550) with MFJ566 DNA, selected at $42{ }^{\circ} \mathrm{C}$, would be inhibited on $0.2 \%$ xylose agar. As none of 93 such transformants displayed xylose inhibition, we concluded that the mutation in MFJ566 did not reside in the $\sec A / \operatorname{div}$ gene. NIG1152(pM J550) itself was not growth-inhibited on xylose plates at its semipermissive temperature of $37^{\circ} \mathrm{C}$.

\section{DISCUSSION}

We have described a lethal phenotype resulting from induced overproduction of SubC'-'LacZ fusion proteins in B. subtilis. As the level of inducer was raised from $0 \cdot 2$ to $2 \%$ xylose, corresponding to only a $2-3$-fold increase in amount of xylose-regulated product (unpublished observations), there was a striking drop in viability. This probably defines the titration point of a component required for protein secretion.

Exploitation of this lethal phenotype for the selection of B. subtilis secretion mutants was impeded by a high mutation frequency in the xylose expression plasmids employed (Hastrup, 1993). Under the selective pressure, $x y l \mathrm{R}$ mutated frequently to a dominant 'super-repressor' phenotype, and mutant plasmid was rapidly established as the sole species. We did not examine whether the mutant repressor proteins were altered in interaction with the operator/promoter, or with the inducer molecule. In other studies, we have noticed that $x y / R$ variants encoding a less effective repressor arise frequently during construction of pSX50 derivatives, with no apparent advantage to the host. It is likely that alternative systems that have been proposed for isolating Bacillus secretion mutants (Zagorec \& Steinmetz, 1990; Nagarajan \& Borchert, 1991) will be hampered by similar problems related to the indicator system regulation. These difficulties may be exacerbated by employing plasmids which replicate via a single-stranded intermediate, and are therefore inherently highly mutable (Gruss \& Ehrlich, 1989).

A screening procedure demanding a smaller proportion of the poison LacZ hybrid protein to be excluded from the cytoplasmic membrane than did our original selection led to identification of the mutant MFJ566. By the rationale behind the screening method, the elevated LacZ activity in MFJ566 at $30^{\circ} \mathrm{C}$ would be due to a reduced ability to transport the LacZ fusion protein from the cytoplasm. This mutant displayed a temperature-dependent, heightened susceptibility to the deleterious effects of subC-lac $Z$ induction.

Consistent with a conditional secretory defect, temperature-shift experiments with SubC and SubC'- 
'PhoA hybrids, as well as $\alpha$-amylase, revealed little or no effect on the level of secreted protein at $30^{\circ} \mathrm{C}$, but a significant deficiency after a shift to the non-permissive $42{ }^{\circ} \mathrm{C}$.

Kinetic analysis of SubC' ${ }^{\prime}$ PhoA demonstrated that this defect correlated with conversion of a much smaller fraction of labelled precursor forms to extracellular protein, compared to the wt (Fig. 3b, c). Increased exoproteolytic degradation, specifically in the mutant, might explain such observations, but we do not believe that this applies to MFJ566. There was evidence of extracellular proteolysis, leading to reductions in the amount of mature PhoA at late chase times, apparent in both wt and mutant, at $30^{\circ} \mathrm{C}$ as well as $42^{\circ} \mathrm{C}$ (Fig. 3a, b, c). However, the intensity of degradation products smaller than PhoA suggests that post-translocational proteolysis could not be the sole factor accounting for the lower steady-state levels of extracellular enzymes in the mutant at $42^{\circ} \mathrm{C}$. In addition, the steady-state levels of SubC (Fig. 2) would argue strongly in favour of diminished production also of other, endogenous, exoproteases in the mutant. Apart from exoprotease levels, incorrect exoprotein folding could lead to higher rates of degradation. In the well-characterized $B$. subtilis $\operatorname{prs} A$ mutants, exoprotein folding is believed to be deficient, and extracellular proteolytic breakdown results in low exoenzyme levels. In these mutants, the kinetics of pre-sequence removal are notably unaffected (Jacobs et al., 1993). In contrast, in MFJ566(pJBA222) this process is slower at $42{ }^{\circ} \mathrm{C}$ (Fig. $3 \mathrm{~b}, \mathrm{c})$, suggesting that entry into the secretory pathway is less efficient. For these reasons it seems likely that the lower extracellular levels of PhoA, and other exoproteins, are a result of reduced translocation, rather than posttranslocational degradation.

For comparative purposes, we performed identical experiments on pJBA222-carrying derivatives of the $B$. subtilis $\sec A$ mutant and its wt control (but shifted up to $37^{\circ} \mathrm{C}$ instead of $42^{\circ} \mathrm{C}$ ). The resulting activities and kinetics were almost indistinguishable from those for MFJ566(pJBA222) (data not shown), and specifically showed, at the non-permissive temperature, a similar degree of precursor persistence in the mutant, and the same striking differences between wt and mutant in amounts of cell-associated mature PhoA and extracellular PhoA at, respectively, early and late chase times (Fig. 3c). We therefore attribute the fading cellular SubC'-'PhoA signal in MFJ566 and div-341 to intracellular proteolysis, due to a failure to engage with the secretory machinery. Taken together, the kinetic data, and the lower membrane-associated steady-state levels of SubC (Fig. $2 \mathrm{~b}$ ), suggest that proteolytic precursor breakdown in MFJ566 occurred at an early stage, prior to membrane association. Indeed, since $\sec A$ in MFJ566 was intact, breakdown probably occurs prior to association with SecA: in E. coli, pre-secretory proteins complex first with $\operatorname{Sec} A$, and are then passed to the integral membrane components of the secretion apparatus.

We were unable to further characterize the genetic nature of the defect in MFJ566. The parental 3G18 had been chosen for mutagenesis as its colonial morphology facilitated the estimation of LacZ activity on plates. $3 \mathrm{G} 18$ proved resistant to PBS1 transduction. Mapping was additionally hampered by exceedingly low congression frequencies, revealed in model transformations with two unlinked chromosomal markers, compared with derivatives of the canonical strain 168 . We thus cannot conclude at present whether a single chromosomal alteration accounts for the whole phenotype of MFJ566, nor whether the diminished secretory proficiency in MFJ566 is due to a lesion in a component of the secretory machinery, or to a less direct effect. This would require the generation of additional alleles in a different genetic background.

While not strictly components of the secretion machinery, E. coli heat-shock proteins DnaJ, DnaK, GroEL and GroES (Kusukawa et al., 1989; Phillips \& Silhavy, 1990; Wild et al., 1992) facilitate protein translocation in their capacity as molecular chaperones, maintaining pre-secretory proteins in a translocation-competent conformation. Chaperone SecB additionally targets some proteins to the secretory apparatus (Hartl et al., 1990). The heat-shock response, or overproduction of DnaK and Dna J, can suppress export defects in secB mutants (Altman et al., 1991; Wild et al., 1992). B. subtilis homologues of the above-mentioned heat-shock proteins have been identified (Zuber \& Schumann, 1994). Acting at a very early stage of translocation, chaperones display a marked selectivity in their interactions (e.g. Kumamoto \& Francetic, 1993). These features make it likely that the defect in MFJ566 involves a chaperone: the variable magnitude of effects on secretory proficiency, and viability, of MFJ566 derivatives secreting different exoproteins suggests a variable requirement for the defective factor. The amount, and nature, of the exoproteins produced, influenced the mutant phenotype. Whether the secretion defect described here resides in a $B$. subtilis homologue of a known secretion locus, or in a novel factor, must await mapping and characterization of the relevant genetic locus, as discussed above.

Judging from the small number, and nature, of secretion mutants that have been identified, it seems likely that $B$. subtilis can tolerate only a marginal limitation of its secretion capacity. The $\sec A$ mutant NIG1152 was identified in a screen for division mutants; its secretion defect was revealed in subsequent analyses (Takamatsu $e t$ al., 1992). In our hands, no scorable difference from wt was observed with the $\sec A / d i v$ - 341 mutant in plate assays for either protease or $\alpha$-amylase secretion at the 'semipermissive' temperature. Moreover, localized mutagenesis of the $B$. subtilis $\sec Y$ gene, whose $E$. coli homologue encodes an essential component of the secretion apparatus, produced only sporulation mutants (Yoshikawa et al., 1993), with no detectable secretion defects (Yoshikawa et al., 1993; R. Freudl, personal communication). It may be significant that like these $\sec Y$ mutants and $\sec A / d i v-341$, sporulation of MFJ566 was depressed ( $13 \%$ vs wt $57 \%$ ).

We have demonstrated that the indirect procedure of screening for raised LacZ activity of a secretory LacZ 
fusion protein can indeed reveal mutants with secretory defects in B. subtilis. A thorough understanding of the Bacillus secretion process will come from a broadly based approach involving genetic screening systems, such as the one described here, to supplement the search for homologues of known secretion loci, and the development of in vitro translocation methods. These should reveal whether the remarkable capacity of the Bacillus spp. to secrete proteins is dependent on any factors unique to these Gram-positive organisms.

\section{NOTE ADDED IN PROOF}

Snyder \& Silhavy (1995) have recently shown that LacZ fusion proteins secreted to the periplasm of $E$. coli can have a toxic effect quite distinct from lethality associated with jamming of the secretory machinery.

\section{REFERENCES}

Altman, E., Kumamoto, C. A. \& Emr, S. (1991). Heat-shock proteins can substitute for SecB function during protein export in Escherichia coli. EMBO J 10, 239-245.

Bassford, P. J., Silhavy, T. J. \& Beckwith, J. R. (1979). Use of a gene fusion to study secretion of maltose-binding protein into Escherichia coli periplasm. J Bacteriol 139, 19-31.

Boylan, R. J., Mendelson, N. H., Brooks, D. \& Young, F. E. (1972). Regulation of the bacterial cell wall: analysis of a mutant of Bacillus subtilis defective in biosynthesis of teichoic acid. J Bacteriol 110, 281-290.

van Dijl, J. M., de Jong, A., Vehmaanpera, J., Venema, G. \& Bron, S. (1992). Signal peptidase I of Bacillus subtilis: patterns of conserved amino acids in prokaryotic and eukaryotic type I signal peptidases. EMBO J 11, 2819-2828.

Errington, J. \& Vogt, C. H. (1990). Isolation and characterization of mutations in the gene encoding endogenous Bacillus subtilis $\beta$ galactosidase and its regulator. $J$ Bacteriol 172, 488-490.

Gardel, C., Benson, S., Hunt, J., Michaelis, S. \& Beckwith, J. (1987). $\sec D$, a new gene involved in protein export in Escherichia coli. $J$ Bacteriol 169, 1286-1290.

Gruss, A. \& Ehrlich, S. D. (1989). The family of highly inter-related ssDNA plasmids. Microbiol Rev 53, 231-241.

Hartl, F.-U., Lecker, S., Schiebel, E., Hendrick, J. P. \& Wickner, W. (1990). The binding cascade of SecB to SecA to SecY/E mediates preprotein targeting to the E. coli plasma membrane. Cell 63, 269-279.

Hastrup, S. (1988). Analysis of the xylose regulon. In Genetics and Biotechnology of Bacilli, vol. 2, pp. 79-81. Edited by A. T. Ganesan \& J. A. Hoch. San Diego: Academic Press.

Hastrup, S. (1993). Gene expression system. European Patent 0242220B1, 21 July 1993.

Hastrup, S. \& Jacobs, M. F. (1990). Lethal phenotype conferred by xylose-induced overproduction of an apr-lac $Z$ fusion protein. In Genetics and Biotechnology of Bacilli, vol. 3, pp. 33-41. Edited by M. M. Zukowski, A. T. Ganesan \& J. A. Hoch. San Diego: Academic Press.

Honda, K., Nakamura, K., Nishiguchi, M. \& Yamane, K. (1993). Cloning and characterization of a Bacillus subtilis gene encoding a homolog of the 54-kilodalton subunit of mammalian signal recognition particle and Escherichia coli Ffh. $J$ Bacteriol 175, 4885-4894.
Jacobs, M. F. (1995). Expression of the subtilisin Carlsbergencoding gene in Bacillus licheniformis and Bacillus subtilis. Gene, 152, 69-74.

Jacobs, M. F., Andersen, J. B., Kontinen, V. \& Sarvas, M. (1993). Bacillus subtilis PrsA is required in vivo as an extracytoplasmic chaperone for secretion of active enzymes synthesized either with or without pro-sequences. Mol Microbiol 8, 957-966.

Jannière, L., Bruand, C. \& Ehrlich, S. D. (1990). Structurally stable Bacillus subtilis cloning vectors. Gene 87, 53-61.

Jeong, S. M., Yoshikawa, H. \& Takahashi, H. (1993). Isolation and characterization of the secE homologue gene of Bacillus subtilis. Mol Microbiol 10, 133-142.

Kontinen, V. P. \& Sarvas, M. (1988). Mutants of Bacillus subtilis defective in protein transport. J Gen Microbiol 134, 2333-2344.

Kumamoto, C. A. \& Beckwith, J. (1983). Mutations in a new gene, $\sec B$, cause defective protein localization in Escherichia coli.J Bacteriol 154, 253-260.

Kumamoto, C. A. \& Francetic, O. (1993). Highly selective binding of nascent polypeptides by an Escherichia coli chaperone protein in vivo. $J$ Bacteriol 175, 2184-2188.

Kusukawa, N., Yura, T., Ueguchi, C., Akiyama, Y. \& Ito, K. (1989). Effects of mutations in heat-shock genes groES and groEL on protein export in Escherichia coli. EMBO J 8, 3517-3521.

Marusyk, R. \& Sargeant, A. (1980). A simple method for dialysis of small-volume samples. Anal Biochem 105, 403-404.

McKenzie, T., Hoshino, T., Tanaka, T. \& Sueoka, N. (1987). A revision of the nucleotide sequence and functional map of pUB110. Plasmid 17, 83-85.

Nagarajan, V. \& Borchert, T. V. (1991). Levansucrase: a tool to study protein secretion in Bacillus subtilis. Res Microbiol 142, 787-792.

Nakamura, K., Takamatsu, H., Akiyama, Y., Ito, K. \& Yamane, K. (1990). Complementation of the protein transport defect of an Escherichia coli secY mutant (secY24) by Bacillus subtilis $\sec Y$ homologue. FEBS Lett 273, 75-78.

Oliver, D. B. \& Beckwith, J. (1981). Escherichia coli mutant pleiotropically defective in the export of secreted proteins. Cell 25, 765-772.

Overhoff, B., Klein, M., Spies, M. \& Freudl, R. (1991). Identification of a gene fragment which codes for the amino-terminal 364 aminoacid residues of a SecA homologue from Bacillus subtilis: further evidence for the conservation of the protein export apparatus in gram-positive and gram-negative bacteria. Mol \& Gen Genet 228, 417-423.

Phillips, G. J. \& Silhavy, T. J. (1990). Heat-shock proteins DnaK and GroEL facilitate export of LacZ hybrid proteins in E. coli. Nature 344, 882-884.

Sadaie, Y. \& Kada, T. (1983). Effect of septum-initiation mutations on sporulation and competent cell formation in Bacillus subtilis. Mol \& Gen Genet 190, 176-178.

Sadaie, Y., Takamatsu, H., Nakamura, K. \& Yamane, K. (1991). Sequencing reveals similarity of the wild-type $d i v^{+}$gene of Bacillus subtilis to the Escherichia coli $\sec A$ gene. Gene 98, 101-105.

Sambrook, J., Fritsch, E. F. \& Maniatis, T. (1989). In Molecular Cloning: a Laboratory Manual, 2nd edn. Cold Spring Harbor, NY: Cold Spring Harbor Laboratory.

Schaeffer, P., Millet, J. \& Aubert, J.-P. (1965). Catabolic repression of bacterial sporulation. Proc Natl Acad Sci USA 54, 704-711.

Schatz, P. J. \& Beckwith, J. (1990). Genetic analysis of protein export in Escherichia coli. Annu Rev Genet 24, 215-248. 
Simon, D. \& Chopin, A. (1988). Construction of a vector plasmid family and its use for molecular cloning in Streptococcus lactis. Biochimie 70, 559-566.

Simons, K., Sarvas, M., Garoff, H. \& Helenius, A. (1978). Membrane bound and secreted forms of penicillinase from Bacillus licheniformis. J Mol Biol 126, 673-690.

Snyder, W. B. \& Silhavy, T. J. (1995). $\beta$-Galactosidase is inactivated by intermolecular disulfide bonds and is toxic when secreted to the periplasm of Escherichia coli. J Bacteriol 177, 953-963.

Suh, J.-W., Boylan, A., Thomas, S. M., Dolan, K. M., Oliver, D. B. \& Price, C. W. (1990). Isolation of a $\sec Y$ homologue from Bacillus subtilis: evidence for a common protein export pathway in eubacteria. Mol Microbiol 4, 305-314.

Takamatsu, H., Fuma, S., Nakamura, K., Sadaie, Y., Shinkai, A., Matsuyama, S., Mizushima, S. \& Yamane, K. (1992). In vivo and in vitro characterization of the $\sec A$ gene product of Bacillus subtilis. $J$ Bacteriol 174, 4308-4316.

Wild, J., Altman, E., Yura, T. \& Gross, C. A. (1992). DnaK and Dna J heat shock proteins participate in protein export in Escherichia coli. Genes \& Dev 6, 1165-1172.

Yoshikawa, H., Jeong, S. M., Hirata, A., Kawamura, F., Doi, R. H. \& Takahashi, H. (1993). Temperature-sensitive sporulation caused by a mutation in the Bacillus subtilis sec $Y$ gene. $J$ Bacteriol 175, 3656-3660.

Zagorec, M. \& Steinmetz, M. (1990). Expression of levansucrase- $\beta$ galactosidase hybrids inhibits secretion and is lethal in Bacillus subtilis. J Gen Microbiol 136, 1137-1143.

Zagorec, M. \& Steinmetz, M. (1991). Construction of a derivative of Tn917 containing an outward-directed promoter and its use in Bacillus subtilis. J Gen Microbiol 137, 107-112.

Zuber, U. \& Schumann, W. (1994). CIRCE, a novel heat shock element involved in regulation of heat shock operon dnaK of Bacillus subtilis. J Bacteriol 176, 1359-1363.

Received 10 January 1995; revised 13 March 1995; accepted 20 March 1995. 